\title{
The Determinants of Unemployment Rate in Jordan: A Multivariate Approach
}

\author{
Mohammad Ibrahim Malawi Alrabba ${ }^{1}$ \\ ${ }^{1}$ Faculty of Business, Tafila Technical University, At-Tafila, Jordan \\ Correspondence: Mohammad Ibrahim Malawi Alrabba, Faculty of Business, Tafila Technical University, \\ At-Tafila, P.O.Box 179, Tafila, 66110, Jordan. E-mail: rabba@ttu.edu.jo
}

Received: September 9, 2017

Accepted:September 27, 2017

Online Published: October 15, 2017

doi:10.5539/ijef.v9n11p109

URL: https://doi.org/10.5539/ijef.v9n11p109

\begin{abstract}
This study aims to investigate the determinants of unemployment rate in Jordan during the period (1992-2015). The Augmented Dickey- Fuller test (ADF) was utilized to examine the stationarity of the variables of this study. The results have shown that the variables are stationary at different orders, $\mathrm{I}(0)$, $\mathrm{I}(1)$, and $\mathrm{I}(2)$. The Granger causality test found that there is a unidirectional causal relationship running from private investment to unemployment rate.

Two tools of analysis were employed: impulse response function and variance decomposition through applying a vector autoregression (VAR) model. The final results have shown that private investment has a negative impact on unemployment rate in Jordan, which explains about $2.64 \%$ of the variations in the unemployment rate in the second period and $(1.58 \%)$ in the fourth period. This percentage also tends to decline to a level at which the explanatory power of private investment for the forecast error in the unemployment rate can reach $1.34 \%$ in the ninth period.
\end{abstract}

Keywords: private investment, unemployment, Jordanian economy

\section{Introduction}

One of the most frequently recurring problems that the world economies face is unemployment. The rates of unemployment are higher in many African and Arab countries. There are of course reasons that exacerbate this problem, such as the inability of government sectors to create new employment opportunities for new labor market entrants (mainly, with the new trends of privatization), the absence of actual encouragement for private investments, and the mismatch between the outputs of educational systems and the labor market needs.

The problem of unemployment is closely linked to the problem of poverty, which altogether has negatively affected the political and social stability and perhaps caused the "Arab Spring". Thus, solving the problem of unemployment contributes significantly to reducing poverty.

To solve the unemployment problem, previous economic studies have focused on the necessity to stimulate private investment and to attract more foreign investments in order to set up new projects or expand existing ones, which leads to raise economic growth rates and to create new jobs, which in turn leads to reduce unemployment rates.

\subsection{The Objective and Importance of the Study}

The Jordanian labor markets is affected by fluctuations in both demand and supply of labor that render it imbalanced, which ultimately causes some major economic problems such as unemployment, which is a big challenge facing the Jordanian labor market.

Official statistics in Jordan indicate that the unemployment rate in the last five years was about $13.5 \%$, unofficial statics, however, indicate that this rate may reach 35\%. Regardless of the accuracy of that number, the Jordanian government concentrates on the task of encouraging private investment policies in order to solve the unemployment problem when it is unable to create new job opportunities during the times where there is an increase in the deficit of the Jordanian general budget.

Unemployment is a serious problem; it can create loss of incomes, cause poverty, and increase social problems that affect individuals and society as a whole. To this end, this study aims to investigate the determinants of 
unemployment rate in Jordan using yearly data during the period 1992-2015. Unlike previous studies, this study is significant in that it focuses on a relatively more recent time period and uses the time series analysis method.

\subsection{Hypotheses of the Study}

This study seeks to check the following hypotheses:

1) Private investment has a negative impact on unemployment rate in Jordan

2) Population growth has a positive impact on unemployment rate in Jordan.

3) Inflation has a negative impact on unemployment rate in Jordan.

\section{Literature Review}

\subsection{Theoretical and Empirical Literature Review}

There are different points of view in the literature about the unemployment problem. Classical methods focus on matters related to the supply side, especially on market mechanism, where flexibility of wages leads automatically to achieve full employment. The Keynesian way of thinking, on the other hand, suggests that the capitalist system cannot have automatic mechanisms that can lead to equilibrium at the full employment level because of rigidity of wages. Additionally, the employment level cannot be determined by the interaction of supply and demand curves in the labor market, but rather by the actual demand on goods and services, from which the demand for labor is derived. Therefore, Keynes suggests stimulating the active demand in goods and services in order to solve that problem.

There are many factors that affect unemployment rates. An increase in private investments leads to stimulate economic activities by increasing already existing productive assets in national economy, expanding existing productive projects or replacing projects whose economic lifetime ended, and buying securities issued to establish new projects that lead to create new job opportunities and decrease unemployment rates, especially in labor-intensive projects (Atamneh \& zo'bi, 2009). It is worth mentioning that a replacement of projects whose economic lifetime ended may not lead to create new jobs, whereas opening up new job opportunities may refer to a project that will be created or projects that have either backward or forward links to the original project.

Population growth is also considered as a one of the main influencing factors on unemployment rates; that is, population growth increases the supply of labor and the unemployment rate consequently rises.

Phillips (1958) indicates that there is an effect of inflation on unemployment rates. By using his curve - known as "Phillips Curve" - Phillips shows that there is a negative relationship between unemployment and inflation. That relationship could be simultaneously considered positive by others; namely, a rise in price levels (inflation) may reduce supply of labor, through the mechanism of replacement labor for leisure time, as a result of decrease in real wages which in turn increases unemployment rates (Aqil et al., 2014).

\subsection{Previous Studies}

Many previous studies touch on the effect of investment, inflation and economic growth on unemployment rates in many regions. In their study, Eita and Ashipala (2010) attempted to find out the reasons of unemployment in Namibia during the period 1971-2007. The results of their study showed that there is a negative relationship between unemployment and inflation. On the other hand, it was found that an increase in investment leads to reduce unemployment rates.

Concerning the pakistanian economy, Rafiq et al (n.d) tried to analyze unemployment determinants during 1998-2008, using population growth rate, inflation rate, and foreign direct investment as explanatory variables. They found that population growth raises unemployment rates which are negatively affected by both inflation rate and foreign direct investment.

Bacerzak and Zurek (2011) aimed to investigate the mutual relationship between foreign direct investment and unemployment in Poland for the period 1990-2009, using vector autoregressive (VAR) model. Their results revealed that an increase in foreign direct investment leads to a decrease in unemployment rates in the Polish economy.

Lacovoiu (2012) studied the effect of investment on unemployment rates in Romania during 2004-2012. The results showed that a decline in net investments in Romania leads to a decrease in the number of the labor workers employed, and consequently to an increase in unemployment rates.

Shaari et al. (2012) examined the effect of foreign direct investment on unemployment rates and economic growth rates in Malaysia in the period 1980-2010. It was found that foreign direct investment contributes to creating new jobs and stimulating economic growth in Malaysia. 
Maqbool et al. (2013) analyzed unemployment determinants in Pakistan during 1976-2012, using autoregressive distributed lag model (ARDL). The results of the study revealed that the main determinants of unemployment are represented by each of gross domestic product (GDP), population number, inflation rate, and of foreign direct investment in both the short run and the long run in Pakistan.

Aqil et al. (2014) invistigated the reasons of unemployment in Pakistan by choosing four unemployment determinants, GDP growth rate, inflation, foreign direct investment (FDI), and population growth. By using correlation and multiple regression model, they found that both of GDP growth rate and inflation have no effect on unemployment, whereas FDI and population growth rate both have a negative effect on unemployment.

Zeb et al. (2014) examined the impact of FDI on unemployment in Pakistan during the period 1990-2011, using an econometrics model that included each of FDI, unemployment, corruption, population number, and inflation. Their study revealed that FDI has a negative effect on unemployment rates.

Chowdhury and Hossain (2014) studied unemployment rate determinants during 2000-2011 in Bangladesh, using a number of variables: unemployment rate, GDP growth rate, exchange rate, and inflation rate. It was found that inflation has a positive effect on unemployment rates, whereas the effects of both of GDP growths rate and exchange rate on unemployment were negative.

With respect to Jordanian economy, Athamneh and Zo'bi (2009) explored the relationship between investment and unemployment in Jordan during the period 1973-2005. The results showed that the average time period allowing investment effects to appear in the labor market in Jordan exceeds two years in all cases; more particularly, the shortest period for Jordanian employment to effect a change in aggregate investment levels was approximately 2.07 years.

\section{The Methodology of the Study}

This study employs both descriptive and econometric methods as well as diagnostic tests, implemented for data analysis based on a proper econometric model during the period 1992-2015. This includes a unit root test, granger causality test, and an optimal lag-length selection test.

\subsection{Descriptive Analysis}

The Jordanian labor market is affected by changes in the internal and external economic situations and by the political situation as well. Such changes render the Jordanian labor market imbalanced. The two wars in 1948 and 1967 resulted in forced migration from Palestine to Jordan, an increase in the population growth, a decrease in the rate of mortality, and an increase in education outcomes of professional employment characterized with high-level skills. In addition, there have been political crises in neighboring countries which also resulted in the entry of large numbers of refugees into Jordan. All of the above factors have led to increase the supply of labor force in the Jordanian labor market (Athamneh, 2008).

The demand for labor in Jordan, on the other hand, has fluctuated in the trajectory of the Jordanian development, depending on the sizes of investment projects as well as on the changing economic and political situations, both in Jordan and in the Arab world. This was the prevailing situation until the seventh decade in the twentieth century. Such factors have affected both the demand and supply of labor; as a result, the Jordanian labor market also became imbalanced (Esa et al., 1989), which caused some economic problems the most significant of which is the continually worsening unemployment. Table 1 indicates a rising in unemployment rates during the period of study; it reaches approximately $14.14 \%$ in that period, where its average maximum rate was $18.8 \%$ in 1993 , while its minimum was $11.1 \%$ in 2014.

With regard to inflation, its rate was $3.44 \%$ on average during the period of the study, with the maximum rate reaching to $13.9 \%$ in 2008 (the end of world financial crises) and the minimum reaching to $-0.9 \%$ in 2015 . Concerning the population growth rate, it was $3.52 \%$ on average during the period 1992-2015. Finally, the annual growth rate of GDP for the private sector was $8.7 \%$ during the period of the study.

Table 1. inflation rate, unemployment rate, population growth rate, and GDP for private sector in Jordan during (1992-2015)

\begin{tabular}{ccccc}
\hline Year & Inflation rate $(\%)$ & Unemployment rate $(\%)$ & Population growth rate (\%) & GDP for private sector * (millions of JD) \\
\hline 1992 & 4 & 18 & 3.86 & 2254.5 \\
1993 & 3.2 & 18.8 & 3.88 & 2401.6 \\
1994 & 3.6 & 15 & 3.67 & 2689.7 \\
1995 & 2.2 & 14.2 & 3.01 & 2832.6 \\
\hline
\end{tabular}




\begin{tabular}{ccccc}
\hline 1996 & 6.6 & 12 & 2.79 & 3041.1 \\
1997 & 3 & 14.4 & 2.81 & 3453.1 \\
1998 & 3.1 & 15.2 & 2.60 & 3578.2 \\
1999 & 0.6 & 15.6 & 2.49 & 3728.7 \\
2000 & 0.7 & 15 & 2.52 & 3729 \\
2001 & 1.8 & 15 & 2.49 & 4105 \\
2002 & 1.8 & 15.3 & 2.41 & 4442 \\
2003 & 1.6 & 14.5 & 2.59 & 4810 \\
2004 & 2.6 & 14.6 & 2.29 & 5321 \\
2005 & 3.5 & 14.8 & 2.24 & 5847 \\
2006 & 6.25 & 14 & 2.07 & 7334 \\
2007 & 4.7 & 13.1 & 2.2 & 8343 \\
2008 & 13.9 & 12.7 & 2.22 & 9052 \\
2009 & -0.7 & 12.9 & 2.22 & 9821 \\
2010 & 4.84 & 12.5 & 2.22 & 10656 \\
2011 & 4.17 & 12.9 & 2.22 & 11562 \\
2012 & 4.51 & 12.2 & 7.427 & 12545 \\
2013 & 4.82 & 12.6 & 8.114 & 12970 \\
2014 & 2.9 & 11.1 & 8.20 & 13410 \\
2015 & -0.9 & 13 & 7.90 & 15485 \\
Average & 3.44 & 14.14 & 3.52 & 6808.81 \\
\hline
\end{tabular}

Source: Jordanian department of statistics, central bank of Jordan, international monetary fund and the World Bank.

(*) Data of this variable obtained for (2000- 2007) from Bani Hani (2013), while the rest of the data estimated with help of annual growth rate over the period (1992-2007).

Table 2 indicates a statistical description for the variables of the study.

Table 2. Descriptive statistics for the variables of the study

\begin{tabular}{ccccc}
\hline & Inflation rate (INF) & private investment (PI) & Population growth (POP) & Unemployment rate (UN) \\
\hline Mean & 3.449583 & 6808.812 & 3.540042 & 14.14167 \\
Median & 3.150000 & 5065.500 & 2.595000 & 14.30000 \\
Maximum & 13.90000 & 15485.00 & 8.200000 & 18.80000 \\
Minimum & -0.900000 & 2254.500 & -2.240000 & 11.10000 \\
Std. Dev. & 2.933899 & 4126.789 & 2.474848 & 1.799497 \\
Skewness & 1.736900 & 0.650045 & 0.493460 & 0.791823 \\
Kurtosis & 7.902278 & 2.033661 & 3.380854 & 3.667593 \\
Jarque- Bera & 36.09962 & 2.624045 & 1.119061 & 2.953614 \\
Probability & 0.000000 & 0.269275 & 0.571477 & 0.228366 \\
Sum & 82.79000 & 163411.5 & 84.96100 & 339.4000 \\
Sum Sq. Dev. & 197.9785 & $3.92 \mathrm{E}+08$ & 140.8720 & 74.47833 \\
Observations & 24 & 24 & 24 & 24 \\
\hline
\end{tabular}

\subsection{Model of the Study}

The econometric model used in this study is based on the economic theories and previous studies such as aqil et al. (2014), maqbool et al. (2013) and rafiq et al (n.d). The model reads as follows:

$$
U N_{t}=F\left(P O P_{t}, I N F_{t}, P I_{t}\right)
$$

$\mathrm{UN}$ in the above model stands for the unemployment rate, POP stands for the growth rate of population, and INF stands for the inflation rate; UN, POP INF are represented in percentage terms in the year $t$. PI represented private investments in the year $t$ as well. Due to difficulty of finding data on private investments in Jordan, this has been replaced by a proxy variable by calculating the percentage of GDP for the private sector in relation to Jordanian GDP in every year of the study.

Rewriting equation in (1) as a linear function takes the following form:

$$
U N_{t}=\alpha+\beta_{1} P O P_{t}+\beta_{2} I N F_{t}+\beta_{3} P I_{t}+U_{t}
$$


Where $\alpha, \beta_{1}, \beta_{2}$, and $\beta_{3}$ are the model parameters, and $\mathrm{U}$ is a random error term.

\subsubsection{The Sources of Data}

This study relies mainly on formal Jordanian statistics issued from the Department of Statistics, Central Bank of Jordan, International monetary Fund, and the World Bank in addition to the data in Bani Hani (2013).

\subsubsection{Diagnostic Tests}

In order to obtain an appropriate estimation formula for the model, a set of diagnostic tests was made before the assessment of the econometric model in this study; the included tests are as follows:

\subsubsection{Unit Root Test}

Most of economic studies which dealt with time series used ordinary least squares method (OLS) without checking the stationarity of the variables used in the econometric model. This may lead to obtain misleading and false results; thus, plenty of statistical problems may consequently emerge due to the use of such traditional models.

One of the most common tests for time series stationarity is Augmented Dickey-Fuller test that examines the existence of unit root hypothesis (and then nonstationarity of time series) as a null hypothesis.

\subsubsection{Granger Causality Test}

This test is considered one of the first tests that emerged in the field of time series analysis; it scrutinizes the existence of a causal relationship between two variables as well as the nature of that relationship and its direction (undirectional or bidirectional), if any (Engle \& Granger, 1987). This test provides the basic principle to Vector Autoregressive (VAR) model, treats all variables of the model in a similar way, and examines the relationship between any two variables by estimating one variable on lag periods of the variable itself and of the other variables using the same lag period, given that past events affect the current ones (Sims, 1980).

Given that, the VAR model is characterized with a set of advantages that are not available in other models (Gujarati \& Porter, 2009); such advantages are:

1) Vector autoregressive is simple since it does not need to identify endogenous or exogenous variables because all variables in this model are considered endogenous variables.

2) Estimation of VAR model is also simple as it uses an Ordinary Least Squares (OLS) method to estimate each equation separately in an integrated model; thus, it looks like a simultaneous equation model.

3) This model predicts better results than many other models that use more sophisticated simultaneous equations.

This study uses two main tools of analysis: variance decomposition and impulse response function. The estimated error for every regression may affect other regression errors via dependent variable in that equation on the ground that it becomes an explanatory variable in other equation. This simultaneous correlation for errors makes it difficult to interpret the model parameters, which prompts users of the vector autoregressive to resort to Cholesky Decomposition that is known for its sensitivity for the model variables arrangement.

At the beginning, a maximum number of lag length must be chosen in a way that allows for maximum amounts of mutual effect among variables. Previous studies relied on determining the number of lag length on Akaike Information Criterio (AIC) and Schwarz Information Criterion (SIC) (Ang, 2007). In addition to the previous criteria just given, recent studies utilized another set of criteria that helped choose the optimal number of lag length in order to make sure about the results and the ability to choose when (AC) and (SIC) are different. The criteria utilized are adjusted test criterion for the likelihood ratio (LR), Hannan-Quinn (HQ) criterion, and Final prediction Error (FPE) criterion.

\section{The Results of Econometric Analysis}

In order to achieve the aim of the study, the researchers have used a method of time series analysis. The results arrived at by employing the diagnostic tests required are described in detail below.

\subsection{The Unit Root Test}

Traditional Augmented Dickey-Fuller (ADF) is used in this study to determine the stationary status, where the unit root is the null hypothesis to be tested.

The results of the unit root test, according to the (ADF) with intercept, are reported in Table 3. The results show that the time series of unemployment rate is stationary at the level; i.e. integrated of order one $\mathrm{I}(0)$, whereas population growth rate and inflation rate are integrated of order one, i.e. I(1), and private investment variable 
becomes stationary at the second difference, i.e. I(2). So, the Vector Autoregression (VAR) model might be an appropriate technique for the current study.

Table 3. Unit Root Test (Augmented dickey- fuller test) with intercept

\begin{tabular}{llcc}
\hline \multicolumn{1}{c}{ Variable } & \multicolumn{1}{c}{ Level } & ADF calculated & Tabulated value at (5\%) \\
\hline Unemployment rate (UN) & At the level & -3.49 & -3.00 \\
Population growth rate (POP) & At the level & -1.09 & -3.00 \\
& At the first difference & -4.65 & -3.01 \\
Inflation rate (INF) & At the level & -2.29 & -3.00 \\
& At the first difference & -4.46 & -3.01 \\
Private investment (PI) & At the level & 2.48 & -3.00 \\
& At the first difference & -1.24 & -3.01 \\
& At the second difference & -4.06 & -3.02 \\
\hline
\end{tabular}

\subsection{Lag Length Selection}

Before estimating the model, the optimal lag length should be selected. Each of the criteria used, such as sequential modified LR test statistic (each test at 5\% level), Final Prediction Error (FPE), Akaike Information Criterion (AIC), Schwarz information criterion (SC), and Hannan- Quinn Information Criterion (HQ), have chosen the optimal number of lag length to be two, which is taken into consideration in the following tests shown in Table 4.

Table 4. Lag-length selection

\begin{tabular}{ccccccc}
\hline Lag & LogL & LR & FPE & AIC & SC & HQ \\
\hline 1 & -277.5678 & NA & 16620903 & 27.95884 & 28.75467 & 28.13155 \\
2 & -259.4301 & 22.45620 & 15642586 & 27.75525 & 29.34690 & 28.10068 \\
3 & -215.9115 & $37.30167^{*}$ & $1809614^{*}$ & $25.13443^{*}$ & $27.52191^{*}$ & $25.65257^{*}$ \\
\hline
\end{tabular}

*indicates the optimal lag length selected by the criterion.

It should be noted that the mechanism of choosing the number of lag length depends on the nature and periodicity of the data used in the analysis. Getting a low number of lag length is usually the case of annual data, but the number of lag length is usually greater when dealing with daily, weekly or monthly data.

\subsection{Granger Causality Test}

Granger causality test is used to determine the direction of the casual relationship among the variables of the study. Table (5) shows the results of the test, where private investment Granger causes unemployment, population growth, and inflation. It is worth mentioning that Granger causality test can show only the direct effect, but the indirect effect may not appear in that test.

\subsection{CUSUM Stability Test}

To examine the stability of the model of the study, CUSUM stability test is utilized. The following figure shows the results found in that test, where the parameters of the model were highly stable during the period of the study; therefore, there is no need to divide the period 1992-2015 to shorter sub periods, so the test can be used for this entire period.

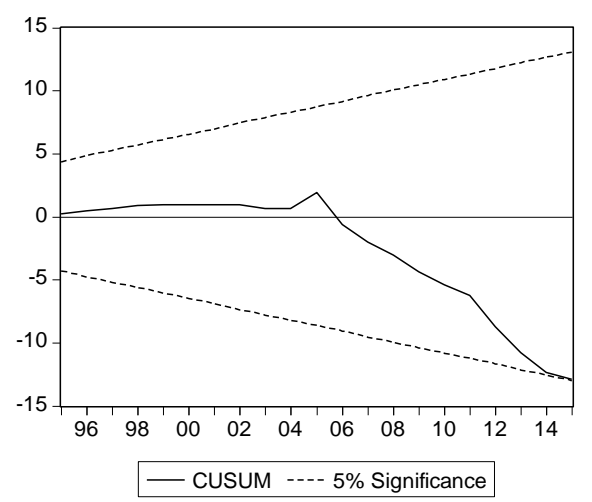


Table 5. Results of causality test among the variables of the study

\begin{tabular}{|c|c|c|c|c|}
\hline $\begin{array}{l}\text { pairwise Granger Causality T test } \\
\text { Date: } 06 / 14 / 17 \text { time: } 15.10 \\
\text { Sample: } 19922015 \\
\text { Lags: } 2\end{array}$ & & & & \\
\hline Null Hypothesis: & Obs & F- Statistics & Probability & State \\
\hline PI does not Granger Cause UN & 22 & 4.50684 & 0.02689 & Reject the null hypothesis \\
\hline UN does not Granger Cause PI & & 0.29267 & 0.74996 & Don't reject the null hypothesis \\
\hline INF does not Granger Cause UN & 22 & 1.33683 & 0.28893 & Don't reject the null hypothesis \\
\hline UN does not Granger Cause INF & & 0.06623 & 0.9361 .6 & Don't reject the null hypothesis \\
\hline POP does not Granger Cause UN & 22 & 0.68150 & 0.51915 & Don't reject the null hypothesis \\
\hline UN does not Granger Cause POP & & 0.65400 & 0.53256 & Don't reject the null hypothesis \\
\hline INF does not Granger Cause PI & 22 & 0.07028 & 0.93240 & Don't reject the null hypothesis \\
\hline PI does not Granger Cause INF & & 3.33116 & 0.06016 & Reject the null hypothesis \\
\hline POP does not Granger Cause PI & 22 & 0.82434 & 0.45531 & Don't reject the null hypothesis \\
\hline PI does not Granger Cause POP & & 3.40678 & 0.05699 & Reject the null hypothesis \\
\hline POP does not Granger Cause INF & 22 & 0.68225 & 0.51879 & Don't reject the null hypothesis \\
\hline INF does not Granger Cause & & 0.09764 & 0.90748 & Don't reject the null hypothesis \\
\hline
\end{tabular}

\section{Vector Autoregression (VAR) Model}

In order to study the relationship between the variables of this study (with a two lag length used in this model), two main tools can be employed: variance decomposition and impulse respond function.

\subsection{Variance Decomposition}

By using this test, we can estimate the amount of the forecast error for each variable due to forecast error in the variable itself as well as the amount that is due to the forecast error in other variables. By applying this test, we can analyze the variance decomposition for the unemployment rate. The results obtained are shown in Table 6 .

The results of the analysis in Table 6 indicate that the unemployment rate is affected by the variable of the population growth rate in Jordan. The third period shows that the variations in the population growth rate could explain about $0.83 \%$ of the forecast error in the unemployment rate. Besides, it should be noted that this percentage increases steadily in later periods, reaching $1.23 \%$ in the sixth period and then beginning to increases during the later period to reach $1.82 \%$ in the tenth period. This signifies the strength of impact of the change in the population growth rate on the unemployment rate, which is not only confined to one period but also to coming periods. This confirms that the impact of the change in the population growth rate on unemployment is going up over time.

The unemployment rate is not only affected by the population growth rate, but also by the inflation rate, as seen in Table 6. It is clear that changes in the inflation rate could explain about $0.096 \%$ of the forecast error in the unemployment rate during the second period. This indicates the percentage of the forecast error of unemployment rate that is due to random shock in inflation rate. Note that this percentage tends to increase slightly in later periods in a slow manner, reaching $0.0999 \%$ in the ninth period, which clarifies the role the inflation rate plays in affecting the unemployment rate. Concerning the impact of private investment on the unemployment rate, Table 6 which also exhibits variations in private investment could explain about $2.64 \%$ of variations in the unemployment rate in the second period and (1.58\%) in the fourth period. This percentage tends also to decline to a level at which the explanatory power of private investment for the forecast error in the unemployment rate can reach $1.34 \%$ in the ninth period.

Table 6. Variance decomposition of UN

\begin{tabular}{cccccc}
\hline Period & S.E. & UN & PI & INF & POP \\
\hline 1 & 1.426458 & 100.0000 & 0.000000 & 0.000000 & 0.000000 \\
2 & 1.765606 & 96.89101 & 2.644101 & 0.096010 & 0.368882 \\
3 & 2.129408 & 97.22581 & 1.839864 & 0.101888 & 0.832441 \\
4 & 2.345045 & 97.43539 & 1.583646 & 0.086368 & 0.894597 \\
5 & 2.563601 & 97.42481 & 1.339765 & 0.091579 & 1.143849 \\
6 & 3.730197 & 97.48707 & 1.191811 & 0.083184 & 1.237940 \\
7 & 2.886936 & 97.35180 & 1.146637 & 0.088345 & 1.413217 \\
8 & 3.020305 & 97.18472 & 1.188988 & 0.090489 & 1.535807 \\
9 & 3.143381 & 96.87100 & 1.343854 & 0.099906 & 1.685237 \\
10 & 3.254647 & 96.45694 & 1.610297 & 0.110412 & 1.822346 \\
\hline
\end{tabular}




\subsection{Impulse Response Function}

Impulse response function (IRF) is the second tool for analyzing the dynamic relationship among the VAR model variables, which comes after variance decomposition (Cholesky Decomposition). IRF shows the response of every endogenous variable in the model to unexpected shocks within error limits of the variables by a standard deviation of one. The following figure shows the IRF for the variable of the unemployment rate to a random shock on each variable of private investment, the population growth rate, and the inflation rate. The figure illustrates that any sudden shock in private investment has a negative impact on the unemployment rate, i.e., any increase in private investment leads to a decrease in the unemployment rate. This impact continues for about two periods, and then diminishes. This result is consistent with the result given by Eita and A shipala (2010).

In terms of the impact of inflation rate on unemployment rate, the results of this study show that it is positive and that it continues for about two periods and then diminishes. This result is consistent with the results of both studies (Maqbool et al., 2013) and (Zeb et al., 2014), but it is inconsistent with the results of Chowdhury and Hossain (2014) and Rafiq et al. (n.d).

Response to Cholesky One S.D. Innovations \pm 2 S.E.
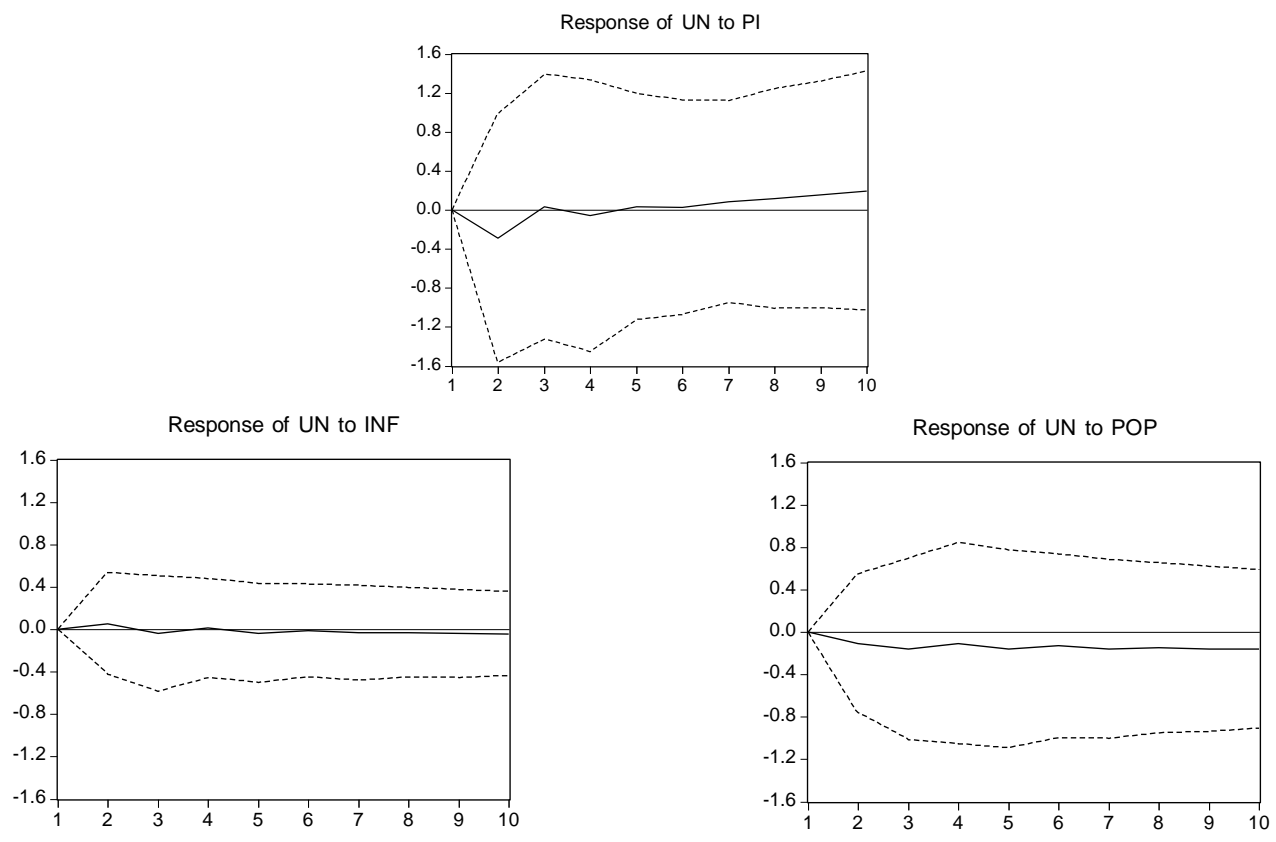

\section{Conclusion}

The conclusion includes the following results and recommendations:

\subsection{The Results}

After applying the required statistical tests in this study to investigate the determinants of unemployment rate in Jordan, it was found that:

1) There is a statistically significant negative effect of private investment on unemployment rate, this result confirms the validity of the first hypothesis of this study, which suggests that there is a negative impact of private investment on unemployment rate.

2) There is a positive impact of inflation rate on unemployment rate, which does not confirm the validity of the third hypothesis of the study.

\subsection{The Recommendations}

According to the above results and in line with the reduction of unemployment rate in Jordan, this study recommends the following:

1) Updating legislations related to promoting private investment like tax exemptions, and facilitating administrative procedures in order to alleviate the problem of unemployment.

2) It can be said that focusing on economic policies, monetary policy and fiscal policy by the government can 
increase investment, which leads to raise economic growth rate, and consequently, reduces unemployment rate in Jordan.

\section{References}

Ang, J. (2007). Financial Deeping and Economic Development in Malaysia. Economic Papers, The Economic Society of Australia, 26(3), 249-260.

Aqil, M., Qurashi, M., Ahmad, R., \& Qadeer, S. (2014). Determinants of Unemployment in Pakistan. International Journal of Physical and Social Sciences, 4(4).

Athamneh, A. B. (2008). The Productivity of Jordanian Labor and Guest Labor an Econometric Analysis for The Period (1973-2009). Abhath Al-Yarmouk, Humanities and Social Sciences, 27(1b).

Athamneh, A. B., \& Al-Zu'bi, B. (2009). The Relationship between Investment and Employment in Jordan: An Econometric Analysis (1973-2005). Dirasat (Administrative Sciences), 36(2).

Bacerzak, A., \& Zurek, M. (2011). Foreign Direct Investment and Unemployment. VAR analysis for Poland in the Year 1995-2009. Europian Research Studies, XIV(1).

Bani, H., \& Reem, M. S. (2013). The Impact of Money Supply on Gross Domestic Product of the Jordanian Private Sector (1992-2007). Unpublished Master Thesis, Department of Economics, Yarmouk University, Irbid, Jordan.

Central Bank of Jordan, Annual Statistical Bulletin, Foreign Sector, (1980-2010).

Central Bank of Jordan, Annual Statistical Bulletin, Money and Banking Guide, (1980-2010).

Chowdhury, M., \& Hossain, M. (2014). Determinants of Unemployment in Bangladesh: A Case Study. Developing Country Studies, 4(3). https://doi.org/10.2139/ssrn.2402908

Department of Statistics, Hashemite kingdom of Jordan, Employment and Unemployment Survey (1980-2010).

Department of Statistics, Hashemite kingdom of Jordan, statistical Yearbook, deferent issues.

Eita, J., \& Ashipala, J. (2010). Determinant of Unemployment in Namibia. International Journal of Business and Management, 5(1). https://doi.org/10.5539/ijbm.v5n10p92

Engle, R., \& Granger, C. (1987). Investigating Causal Relations by Econometrics Model and Cross-Spectral Methods. Econometrica, (22), 117-129.

Esa, I., AlShahateet, M., \& AlShraideh, B. (1989). A Study of the Status and Future of Jordanian Labor Market. $3^{\text {rd }}$ Part, Database of the Jordanian Labor Market, Royal Scientific Society, Amman, Jordan.

Gujarati, D., \& Porter, D. (2009). Basic Econometrics (5th ed.). McGraw Hill.

Lacovoiu, V. (2012). Impact of Capital Investment on Unemployment in the Context of Economic Crises: The Case of Romania. Economic Insights- Trends and Challenges, LXIV(2).

Maqbool, M., Abdul, S. T., \& Bhalli, M. (2013). Determinants of Unemployment: Emoirical Evidences from Pakistan. Pakistan Economic and Social Review, 51(2).

Philips, A. W. (1958). The Relation Between Unemployment and the Rate of Change in Money Wage Rates in the United Kingdom. Economica, 25, 100.

Rafiq, M., Ahmad, I., Ullah, A., \& Khan, Z. (n. d.). Determinants of Unemployment: A Case Study of Pakistan Economy (1998-2008). Abasyn Journal of Social Sciences, 3(1).

Shaari, M., Hossain, N., \& Ab. Halim, M. (2012). The Impact of Foreign Direct Investment on Unemployment Rate and Economic Growth in Malaysia. Journal of Applied Sciences Research, 8(9).

Sims, C. A. (1980). Macroeconomics and Reality. Econometrica, 48(1). https://doi.org/10.2307/1912017

Zeb, N., Qiang, F., \& Sharif, M. (2014). Foreign Direct Investment and Unemployment Reduction in Pakistan. Int. j. Eco. Res., 5(2).

\section{Copyrights}

Copyright for this article is retained by the author(s), with first publication rights granted to the journal.

This is an open-access article distributed under the terms and conditions of the Creative Commons Attribution license (http://creativecommons.org/licenses/by/4.0/). 